\title{
TUTURAN MEKUKU SISTEM PENANDA ETNIS DALAM INTERAKSI SOSIAL SUKU TOLAKI DI SULAWESI TENGGARA
}

\section{MEKUKU UTTERANCE: ETHNIC SIGNIFIER SYSTEM IN SOCIAL INTERACTION OF TOLAKI SOCIETY IN SOUTHEAST SULAWESI}

\author{
Zakiyah Mustafa Husba \\ Kantor Bahasa Provinsi Sulawesi Tenggara \\ Jalan Haluoleo, Kompleks Bumi Praja, Anduonohu, Kendari \\ Email: kyamusba@gmail.com
}

\begin{abstract}
Abstrak
Mekuku merupakan salah satu sistem bertutur silsilah yang dilakukan oleh masyarakat Tolaki dalam interaksi sosial situasi formal dan nonformal. Meskipun telah menjadi tradisi yang dilakukan secara turun temurun, mekuku tidak dilakukan dalam tradisi yang bersifat ritual. Secara garis besar, mekuku disajikan dengan menggunakan dua media ujaran, yaitu pertanyaanpertanyaan khusus dan deskripsi berbentuk prosa. Kedua media ujaran mekuku tersebut samasama akan menghasilkan jawaban yang isinya dapat menjelaskan silsilah seseorang berdasarkan status sosial seseorang. Penelitian ini difokuskan pada penanda etnis yang terdapat dalam mekuku sebagai sebuah sistem yang dapat digunakan untuk menandai status seseorang dalam masyarakat. Masyarakat yang dimaksud di sini tentunya masyarakat yang berasal dari kelompok etnis yang sama. Penelitian ini bertujuan untuk mengungkapkan tuturan mekuku yang di dalamnya mengandung penanda-penanda khusus yang dapat menandai status sosial seseorang. Hasil penelitian menunjukkan bahwa dalam tuturan mekuku terdapat penanda etnis yang digunakan sebagai alat bantu menentukan status sosial seseorang.
\end{abstract}

Kata kunci: penanda etnis, interaksi sosial, suku Tolaki, Mekuku.

\begin{abstract}
Mekuku is one of genealogy utterance systems, which applied by Tolaki society in formal and informal situations. Although it has been a tradition for Tolaki society, Mekuku is not applied in the ritual tradition. Mainly, Mekuku is presented in two forms through specific questions and prose. These both forms provide answers, which describe the genealogy of a person in the society. This study focused on ethnic signifier in Mekuku as a system used to remark a persons' social status in the society who come from the same ethnic group. The purpose of this study was to analyze Mekuku's utterances that contain specific signifiers to remark a persons' social status. The result of study showed that there were ethnic signifiers in Mekuku's utterances, which used to determine social status of a person in the society.
\end{abstract}

Keywords: ethnic signifier, social interaction, Tolaki society, Mekuku.

\section{A. PENDAHULUAN}

Suku Tolaki adalah satu kelompok etnik dari beragam komunitas etnik besar yang mendiami wilayah Sulawesi
Tenggara. Wilayah yang didiami oleh penduduk Sulawesi Tenggara terdiri atas wilayah kepulauan dan wilayah daratan dan orang Tolaki merupakan penduduk asli 
yang mendiami wilayah daratan. Mereka hidup dan berkembang dalam lingkungan sosial budaya yang heterogen. Keberadaan ini menjadikan etnis Tolaki sebagai bagian dari etnis yang heterogen yang otomatis terlibat langsung dalam proses interaksi dan komunikasi bersama beragam etnis yang lain. Dengan adanya interaksi yang beragam dalam lingkungan yang heterogen tersebut memungkinkan terjadinya upaya penonjolan identitas diri dari setiap masing-masing etnis.

Upaya penonjolan identitas merupakan salah satu cara dalam mengindentifikasi potensi kekayaan budaya masing-masing suku. Dan upaya tersebut bukanlah hal yang mudah karena setiap daerah memiliki tradisi dan sistem budaya yang terefleksikan dengan caranya masing-masing khususnya dalam berinteraksi. Sebagaimana kita ketahui, ada bentuk-bentuk pengungkapan budaya seperti cerita rakyat, dongeng, mitos, legenda atau cerita-cerita berisi sejarah sebuah tempat, peristiwa, tokoh yang dihasilkan untuk mengenalkan pengalaman masa lalu pada generasi penerus. Dengan cara ini oleh penuturnya dijadikan kebiasaan atau tradisi dalam lingkungan keluarga, kelompok, dan masyarakat. Seperti halnya daerah di berbagai penjuru Nusantara yang menganut sistem bertutur lisan sebagai sebuah tradisi masyarakat yang mengiringinya.

Interaksi sosial dalam masyarakat yang heterogen memungkinkan penguatan dalam proses menonjolkan identitas diri, baik dalam komunitas itu sendiri dengan tujuan pelestarian nilai-nilai hidup, maupun di luar komunitas itu dengan tujuan sebagai eksistensi budaya (selfculture eksistence). Menurut Sedyawati (dalam warta ATL, 1996: 5) tradisi bertutur memiliki aspek sosial dan aspek budaya di dalamnya. Aspek sosial meliputi para pelaku yang terlibat, tujuan kegiatan pelaku, dan sistem penyelenggaraan tradisi lisan yang bersangkutan sedangkan aspek budaya berkaitan dengan berbagai pesan yang dikandung dalam tradisi lisan dan bagaimana kaidah penyelenggaraan dan simbol yang digunakan. Tradisi lisan merupakan bagian dari peristiwa sosial budaya. Oleh karena itu tradisi lisan berkaitan dengan konteks masyarakat penghasil tradisi yang bersangkutan dan masyarakat penikmatnya.

Ranah budaya Tolaki adalah salah satu istilah untuk menyebut wilayah bekas kekuasaan Kerajaan Konawe dan Mekongga, wilayah kekuasaan penguasa dan pemimpin adat Tolaki di masa lalu. Batas-batas wilayah inilah yang dianggap memiliki cerita sejarah terbentuknya wilayah kekuasaan, baik dari segi geografis, maupun sebagai wilayah adat. Masyarakat Tolaki termasuk yang melakukan kegiatan bertutur tradisional sebagai satu sistem komunikasi dalam berinteraksi. Salah satu tradisi bertutur yang terkenal dari budaya Tolaki adalah mekuku. Mekuku adalah sebuah cara bertutur silsilah yang sebagian kecil kelompoknya menjadikan cara ini sebagai sebuah tradisi. Silsilah dalam bahasa Tolaki disebut kukuaha. Tradisi yang dimaksud dalam mekuku ini tidak berfungsi ritual seperti halnya tradisi lisan dalam upacara-upacara adat (Taridala, 2005, dan Abdullah, 2009). Masyarakat Tolaki yang pada awalnya tidak mengenal tradisi tulis sebagaimana yang terjadi pada masyarakat Sulawesi Tenggara di wilayah kepulauan, menjadikan mekuku sebagai satu sistem interaksi dan komunikasi yang selanjutnya menjadi cikal bakal bentuk tradisi lisan bercerita masyarakat Tolaki. Mekuku telah menjadi kebiasaan sejak dulu dan masih berlangsung hingga saat ini.

Dilihat dari situasinya, mekuku biasa dilakukan pada situasi resmi dan tidak resmi, serta menjadi sebuah sistem komunikasi yang memiliki peran penting dalam proses identifikasi kelompok sosial. Bentuk mekuku resmi dan tidak resmi ditetapkan oleh masyarakat Tolaki. Dalam situasi tak resmi, mekuku biasa dilakukan dalam lingkup sosial yang lebih kecil yaitu pada tingkat keluarga inti dan kerabat dekat. Mekuku dalam situasi ini dilakukan 
di tempat dan waktu yang tidak resmi. Biasanya dilakukan di rumah dan hanya dihadiri oleh keluarga inti serta kerabat terdekat. Setiap anggota keluarga dibagikan lembar silsilah lalu dibacakan oleh orang tertua di dalam keluarga inti. Tujuannya untuk mengingatkan seluruh anggota keluarga tentang asal-usul rumpun mereka. Bentuk tuturan ini tidak ditentukan waktunya dan bisa dilakukan kapan saja.

Adapun mekuku dalam situasi resmi dilakukan pada tempat dan waktu yang telah ditentukan. Biasa dilakukan rumah salah seorang petinggi adat atau di tempat pertemuan yang dihadiri oleh tamu undangan dari berbagai suku. Mekuku dalam situasi resmi dapat dijumpai dalam rangkaian upacara adat perkawinan. Silsilah dibacakan oleh pembicara adat yang biasa disebut pabithara dari pihak laki-laki dan perempuan dengan tujuan agar status kedua mempelai dapat diketahui (Abdullah, 2009: 186 - 188). Mekuku dalam situasi resmi lainnya dapat dilihat dalam proses hukum adat, seperti dalam penyelesaian sengketa tanah adat (Koodoh, 2011: 29).

Selain sebagai satu bentuk interaksi dan komunikasi antarpersona, mekuku dijadikan sebagai alat pembuktian dalam sebuah proses hukum, khususnya yang berkaitan dengan hukum adat. Bagi masyarakat Tolaki, mekuku telah menjadi salah satu proses identifikasi antarkeluarga, kelompok, dan antarmasyarakat dalam budaya yang berbeda. Dilihat dari proses penyajiannya, mekuku dapat dikenali dalam dua bentuk, yaitu bentuk ujaran atau pernyataan dan ujaran dalam bentuk prosa.

Bagi sekelompok kecil (anak-anak dan remaja) yang hidup di era modern seperti saat ini, mekuku dianggap sebagai suatu kegiatan yang tidak penting, membosankan, dan banyak menyita banyak waktu. Hal ini dapat dipahami, mengingat secara teknis, seperti yang telah diuraikan sebelumnya, mekuku yang dilakukan dalam situasi tidak resmi yang dituturkan oleh para orang tua, bisa dilakukan dalam waktu berjam-jam dalam sehari, meskipun dilakukan pada waktu senggang atau sedang santai. Tujuannya adalah untuk memperkenalkan rumpun keluarga, rumpun wilayah, dan untuk menentukan status sosial seseorang. Pada situasi yang resmi, mekuku dilakukan berbeda dengan pada situasi tidak resmi, dilihat dari tujuan dan kepentingannya. Bertutur silsilah dalam situasi resmi justru harus dilakukan dengan tujuan tertentu, misalnya dalam proses hukum penyelesaian kasus sengketa hak kepemilikan tanah.

Hal yang menjadi menarik adalah ketika mekuku yang oleh sebagian masyarakat Tolaki, khususnya para remaja dan anak muda masa kini yang menganggap diri sebagai masyarakat modern, dianggap sebagai hal yang tidak penting dan membosankan itu, ternyata memiliki nilai sosialitas yang tinggi karena mengandung aspek-aspek penting yang berpengaruh terhadap cara berpikir, cara berinteraksi, dan cara pandang seseorang terhadap orang lain. Melalui tulisan ini, penulis untuk mengangkat dua hal penting, yaitu 1) bagaimana mekuku dalam bentuk pertanyaan dan bentuk prosa? 2) bagaimana mekuku menjadi sarana identifikasi bagi masyarakat dalam kelompok dan di luar kelompok penuturnya?

Pendekatan ilmu sastra dalam perspektif struktural dilakukan untuk membahas mekuku dalam bentuk prosa. Masyarakat Tolaki menyusun silsilah dan asal-usul kedatangan rumpun mereka melalui bentuk cerita yang secara struktur memenuhi kriteria bentuk prosa. Prosa terbagi atas bentuk dan isi. Antara bentuk dan isi keduanya saling terkait dan merupakan satu kesatuan yang utuh (Ratna, 2007: 515). Pendekatan struktural diterapkan untuk mengetahui isi cerita dalam mekuku yang berkaitan dengan sistem sosial masyarakat penuturnya. Lebih jauh dikatakan oleh Taum (2011: 257) terkait prinsip struktural bahwa 
elemen-elemen sastra seperti alur, tema, perwatakan, dan citraan selalu ditemukan dalam bentuk sastra lisan. Artinya, tema cerita, nama tokoh, alur peristiwa, serta latar tempat dan waktu yang terdapat dalam struktur cerita mekuku merupakan fakta sosial masa lalu yang dapat ditelusuri dan dikaitkan dengan fakta sosial masa kini. Mekuku bukan merupakan hasil sastra lisan, tetapi karena bentuk pengungkapan silsilahnya melalui tuturan, maka mekuku dapat menampakkan ciri kelisanannya.

Dengan mengetahui penjelasan tentang proses pengungkapan silsilah oleh masyarakat Tolaki dapat diketahui cara masyarakat Tolaki menelusuri silsilah atau hubungan kekerabatan antarmasyarakat penutur, khususnya melalui ujaran dan pertanyaan mekuku. Selain itu, dapat diketahui pula proses identifikasi silsilah kekerabatan antarmasyarakat Tolaki yang disajikan dalam bentuk prosa dan bentuk pertanyaan-pertanyaan. Kebiasaan bertutur silsilah oleh masyarakat Tolaki ini sebagian besar masih dilakukan di wilayah Konawe dan Konawe Selatan yang penduduknya merupakan penduduk asli orang Tolaki.

Dalam bukunya tentang Kukuaha, Nurdin Abdullah (2009) membahas kukuaha dari segi asal usul manusia Tolaki, wilayah pemukiman pemerintahan Kerajaan Tolaki di masa lalu, serta silsilah orang Tolaki dan perkembangannya. Fokus pembahasan dalam buku ini adalah asal usul orang Tolaki dilihat dari silsilah (kukuaha) raja-raja di masa lalu. Buku ini juga berisi kumpulan naskah silsilah (kukuaha) dari penguasa pemerintah masa lalu dari berbagai versi dan sumber.

Buku ini terkait dengan pembahasan tulisan ini karena memuat berbagai peristiwa tentang asal usul wilayah dan silsilah raja-raja Tolaki di masa lalu. Mekuku dalam bentuk prosa yang akan dibahas dalam tulisan ini memuat cerita tentang peristiwa dan silsilah di masa lalu. Buku ini juga menggambarkan model silsilah Tolaki sehingga dapat menjadi rujukan bagi masyarakat non Tolaki yang bermukim di Sulawesi Tenggara untuk mengetahui sistem silsilah Tolaki.

\section{B. METODE PENELITIAN}

Tulisan ini merupakan hasil penelitian yang telah dilakukan di Desa Ranomeeto, Kabupaten Konawe Selatan. Data yang digunakan adalah data primer berupa ujaran-ujaran pertanyaan yang digunakan dalam mekuku dan data sekunder berupa manuskrip yang berisi teks prosa yang diperoleh dari informan penutur bahasa Tolaki yang berlokasi di Desa Ranomeeto, Kabupaten Konawe Selatan. Pada tahap analisis data, akan digunakan teknik deskriptif dengan tahapan berikut; 1) memberikan interpretasi dari sumber data; 2) menganalisis makna yang terkandung dalam data untuk memeroleh jawaban atas permasalahan dalam penelitian ini.

Konsep struktur sastra digunakan dalam penelitian ini. Khazanah kebudayaan dalam bentuk bahasa salah satu yang termasuk di dalamnya adalah sastra lisan. Bentuk-bentuk karya lisan tersebut dapat dikenali seperti dongeng, legenda, cerita mitos, nyanyian, pepatah, dan sebagainya. Sebuah karya yang oleh penuturnya diakui sebagai sebuah hasil interaksi sosial, maka hal itu telah menjadi cara yang hidup dan telah lama ada sebagai kelangsungan dari tradisi lisan dan komunikasi lisan. Sebagian bentuk kukuaha ada yang berbentuk prosa dan teknis penyajiannya seperti halnya membacakan cerita. Menurut Fuglesang, ahli komunikasi, sastra, dan budaya, secara struktur, bentuk budaya lisan umumnya sederhana, berfungsi efisien dan umumnya memperlihatkan nilai-nilai secara estetis (Fuglesang dalam Eilers, 1987: 73). Dengan kata lain bahwa melalui bentuknya yang sederhana namun dapat menampilkan nilai estetis itulah yang kemudian dianggap sebagai hasil sastra. Masih menurut Fuglesang, bahwa budaya lisan pada akhirnya dilestarikan dalam bentuk puisi (pepatah, teka-teki, nyanyian, lagu, dan cerita). Bentuk lainnya yang lebih 
bervariasi adalah dongeng, legenda prosa epik, dan balada. Bentuk-bentuk lisan ini sebenarnya merupakan perwujudan ekspresi dari semua pengalaman dan cara berinteraksi penuturnya dalam upaya menunjukkan sebuah peradaban lisan.

Setiap masyarakat memiliki aturan dan norma dalam melakukan hubungan komunikasi dan interaksi sosial. Kebanyakan ahli sastra mengemukakan struktur sebuah karya sastra penekanannya pada kekhasan gaya bahasanya atau stilistika, berupa pemakaian bahasa secara universal maupun yang merupakan ciri dari masing-masing penciptanya. Pola-pola komunikasi lisan tentu berbeda dengan pola komunikasi tulis. Struktur sastra dengan pola komunikasi lisan pada dasarnya ditekankan pada pembicara. Dengan kata lain, pembicara atau pencerita mempunyai peran penting dalam penyampaiannya. Adapun pada pola komunikasi tulis, penekanan penyampaiannya terletak pada pesan dan pembaca. Tentang komunikasi dan interaksi Proses komunikasi yang dilakukan dalam sebuah tradisi tertentu sangat berkaitan dengan konsep pewarisan sebuah budaya secara turun temurun dan bagian diri manusia sebagai makhluk sosial. Dalam hal ini, bahwa manusia berinteraksi dalam konteks tertentu sesuai kebutuhannya. Peristiwa komunikasi meliputi tiga hal, yaitu medan atau field, suasana atau tenor, dan cara atau mode (Suhardi dan Sembiring, dalam Kushartanti, dkk. 2007: 49).

Medan merupakan istilah yang mengacu pada hal atau topik, yaitu tentang apa bahasa itu dipakai. Ketika ujaran dihubungkan dengan kegiatan tertentu yang sedang berlangsung, maka bidangnya adalah kegiatan itu sendiri. Medan merupakan subjek atau topik dalam teks suatu pembicaraan. Terdapat banyak contoh medan, misalnya, ekonomi, sosial, politik, teknologi, budaya. Suasana (tenor) mengacu pada peran peserta tuturan atau pembicaraan, yakni hubungan sosial antara penutur atau pembicara dengan mitra tutur (pendengar) yang ada dalam teks atau pembicaraan tersebut. Suasana menekankan bagaimana pemilihan bahasa dipengaruhi oleh hubungan sosial antara peserta tutur. Suasana juga dapat memengaruhi pemilihan ragam bahasa ke dalam pembagian gaya berbahasa, seperti ragam intim, santai, formal, dsb. Cara (mode) mengacu pada peran yang dimainkan bahasa dalam komunikasi termasuk di dalamnya peran yang terkait dengan jalur yang digunakan ketika berkomunikasi. Jalur komunikasi yang dimaksud adalah pesan yang disampaikan dengan bahasa tulis, lisan, lisan utuk dituliskan, atau sebaliknya tulis untuk dilisankan. Cara juga berhubungan dengan ragam retoris yang dipakai, misalnya bahasa persuasif, performatif, atau naratif.

\section{HASIL DAN BAHASAN \\ 1. Pendekatan Identitas Etnis dalam Komunikasi}

Salah satu fungsi bahasa adalah alat komunikasi atau alat interaksi. Secara umum ada tiga komponen yang harus selalu ada dalam setiap proses komunikasi, yaitu 1) pihak yang berkomunikasi, pengirim informasi (komunikator) dan penerima informasi (komunikan); 2) informasi yang dikomunikasikan; 3) alat yang digunakan dalam proses komunikasi tersebut. Pihak yang terlibat dalam proses komunikasi adalah dua orang, atau dua kelompok orang, sebagai pengirim dan penerima pesan. Informasi yang disampaikan merupakan suatu ide, gagasan, keterangan, atau pesan. Adapun alat yang digunakan dapat berupa simbol atau lambang seperti bahasa; berupa tandatanda; gambar atau petunjuk, dan dapat juga alat yang bersifat gerak-gerik anggota badan (kinesik) (Chaer, 2004: 14).

$$
\text { Setiap kegiatan yang }
$$

menghasilkan informasi biasanya dikaitkan dengan kebiasaan budaya dalam satu masyarakat tertentu. Berlangsungnya komunikasi bahasa dalam suatu peristiwa sosial khususnya yang berkaitan dengan 
sistem budaya tertentu berkaitan dengan pihak-pihak yang bertutur dalam satu peristiwa dan tempat, serta keperluan tertentu. Lebih lanjut Chaer mengemukakan bahwa peristiwa tutur yang dimaksud tersebut pada dasarnya merupakan rangkaian dari sejumlah tindak tutur yang terorganisasikan untuk mencapai suatu tujuan. Jika peristiwa tutur merupakan gejala sosial dalam konteks tertentu, maka tindak tutur merupakan gejala individual, bersifat psikologis, dan keberlangsungannya ditentukan oleh kemampuan bahasa si penutur dalam menghadapi situasi tertentu. Tindak tutur dan peristiwa tutur merupakan dua gejala yang terdapat dalam satu proses, yaitu proses komunikasi (2004: 50).

Proses komunikasi yang dilakukan dalam sebuah tradisi tertentu sangat berkaitan dengan konsep pewarisan sebuah budaya secara turun temurun dan bagian diri manusia sebagai makhluk sosial. Dalam hal ini, bahwa manusia berinteraksi dalam konteks tertentu sesuai kebutuhannya. Identitas etnis sering digunakan dalam kajian sosiologi, antropologi, psikologi, dan sejarawan. Pendekatan ini digunakan untuk mengkaji asal-usul, substansi, konsekuensi, dan proses etnisitas yang mengalami perubahan dalam satu atau berbagai komunitas kultural. Dalam berbagai disiplin ilmu, identitas etnik berkaitan erat dengan konsep etnisitas (ethnicity), dan konsepdiri kultural atau rasial. Ada dua pendekatan yang sering digunakan oleh para ahli terhadap identitas etnik, yaitu pendekatan objektif atau yang dikenal dengan pendekatan struktural, dan pendekatan subjektif atau yang disebut dengan pendekatan fenomenologis (Mulyana, 1998: 151).

Perspektif objektif atau pendekatan struktural cenderung melihat sebuah kelompok etnik sebagai kelompok yang bisa dibedakan dari kelompokkelompok lainnya berdasarkan ciri-ciri budayanya, seperti bahasa, agama, asalusul kebangsaan. Dengan kata lain pendekatan ini cenderung menganggap etnisitas sebagai sesuatu yang bersifat statis. Adapun perspektif subjektif atau fenomenologis memandang etnisitas sebagai suatu proses ketika orang-orang mengalami atau merasakan diri mereka sebagai bagian dari suatu kelompok etnik yang diidentifikasi oleh orang lain atau kelompok lain. Dengan kata lain etnisitas dalam pandangan ini dianggap sebagai sesuatu yang bersifat dinamis.

Lebih jauh dikatakan oleh Shibutani (dalam Mulyana: 155) bahwa secara tradisional, etnisitas dipandang sebagai seperangkat ciri sosiokultural yang membedakan kelompok-kelompok etnik antara yang satu dengan lainnya. Secara fenomenologis, identitas etnik satu kelompok yang menonjolkan diri mereka melalui tanda-tanda budaya, seperti bahasa dan proses interaksi mereka dengan kelompok lain. Proses komunikasi dan berinteraksi ini ditonjolkan dalam satu bentuk tradisi atau cara berkomunikasi secara turun temurun yang dapat dikenali sehingga berbeda dengan komunitas atau kelompok budaya yang lain.

Dalam proses komunikasi kultural, identitas etnik dapat dikaitkan dengan konsep penyingkapan diri atau self disclosure dalam upaya meningkatkan kualitas hubungan komunikasi dalam satu pola interaksi yang sama. Penyingkapan diri merupakan suatu usaha untuk membiarkan keontetikan, kecirian, kekhasan secara etnik memasuki hubungan sosial, baik itu individu ataupun kelompok, yang tujuannya sangat berkaitan erat dengan pengembangan konsep diri dan pencitraan (L. Tubs dan Moss, 2000: 12).

Penyingkapan diri tidak hanya merupakan bagian intergral dari komunikasi antarorang per orang, tetapi lebih sering muncul dalam konteks dua orang dalam konteks jenis komunikasi lainnya. Artinya, dalam konteks komunikasi pada kultur yang sama, penyingkapan diri menjadi salah satu upaya meningkatkan kualitas hubungan komunikasi pada tingkat keakraban, serta 
secara psikologis memberi efek kepuasaan pribadi atas identitas yang dimiliki sebagai bagian dari kelas sosial tertentu, misalnya kelas bangsawan.

\section{Tentang Mekuku, Bentuk, dan Jenisnya}

Masyarakat Tolaki dikenal sebagai komunitas yang tidak menyukai tradisi menulis. Mereka cenderung lebih banyak menceritakan peristiwa atau hikayathikayat klasik kepada orang lain lewat penuturan yang berawal dari tradisi mekuku (Taridala, 2005; 97). Tradisi ini dipandang sebagai salah satu wahana penuturan sejarah atau riwayat peristiwa klasik masa lalu. Antro-prosentrisme dalam tradisi ini sangat menonjol, namun dalam proses penceritaan kiprah personal di masa lalu, orang Tolaki biasa melengkapinya dengan latar peristiwa yang mengitarinya. Melalui tradisi inilah bisa diperoleh berbagai peristiwa yang tidak didokumentasikan dalam naskah-naskah tertulis.

Istilah kukuaha atau yang disebut silsilah suku bangsa Tolaki pada zaman dahulu kala belum dikenal seperti sekarang, bahkan dalam penyusunannya pula belum sistematis karena pada masa itu kehidupan masyarakat Tolaki masih belum mengenal bahasa tulisan. Tetapi dalam perkembangannya telah banyak mengalami perubahan yang disesuaikan dengan perkembangan zaman.

Orang Tolaki pada umumnya suka memilih pemukiman di lokasi tertentu di daratan yang tidak jauh dari gunung, dekat sungai, dan ada juga yang tinggal tidak jauh dari pantai. Pada dasarnya penduduk Tolaki dikenal bukan sebagai kelompok etnis perantau. Oleh karena itu keberadaan orang Tolaki di daerah lain tidak membentuk satuan pemukiman dengan sistem sosial tersendiri, melainkan hanya menjadi bagian kecil dari pemukiman atau komunitas setempat. Tradisi berpindah dan bermukim di daerah lain dalam pengertian merantau tidak dijumpai secara utuh dalam tradisi migrasi di kalangan masyarakat Tolaki, baik dilihat dari aspek penyebabnya, maupun dari aspek dinamika sosial. Perpindahan beberapa orang atau kelompok keluarga terjadi tidak secara terorganisir, hanya dengan tujuan memenuhi hajat tertentu dan dalam tempo yang telah ditentukan.

Masyarakat Tolaki yang hidup dan berkembang dalam lingkungan heterogen sosial budaya di wilayah Sulawesi Tenggara, menjadikan etnis Tolaki sebagai bagian dari etnis yang heterogen yang terlibat dalam proses interaksi dan komunikasi bersama beragam etnis yang lain. Proses interaksi dalam lingkungan yang heterogen tersebut memungkinkan sebuah upaya penonjolan identitas diri dari masyarakat masing-masing etnis. Interaksi sosial dalam masyarakat yang heterogen memungkinkan satu komunitas menonjolkan identitas diri, baik dalam komunitas itu sendiri dengan tujuan pelestarian nilai-nilai hidup, maupun di luar komunitas itu dengan tujuan sebagai eksistensi budaya (self-culture eksistence).

Silsilah atau kukuaha Tolaki yang dikenal mulai tumbuh dan berkembang sejak di masa pemerintahan Raja Tebawo atau Rebi yang diakui kalangan suku bangsa Tolaki pada masa itu sebagai ahli hukum adat. Sumber informasi yang diperoleh tentang kukuaha Tolaki sebagaimana yang pernah ditulis oleh Nurdin Abdullah berjudul Silsilah Tolaki Kukuaha (2009 : 182) menyebutkan ada 4 (empat) model kukuaha, yaitu

1. Pekuku totaenango, artinya silsilah Tolaki yang dialunkan dalam bentuk nyanyian pada saat-saat tertentu seperti pesta adat di malam hari, karena pada masa itu belum ada media elektronik, seperti radio atau televisi sebagai sarana hiburan rakyat;

2. Pekuku tenango, artinya penceritaan kembali apa yang pernah didengar dari cerita rakyat secara turun temurun tentang silsilah Tolaki;

3. Pekuku tula-tula, artinya cerita silsilah yang dituturkan pada saat-saat tertentu sewaktu orang-orang tua pemuka adat berkumpul untuk didengarkan 
bagaimana pemahaman mengenai silsilah Tolaki dengan maksud untuk saling mencocokkan susunannya mulai dahulu kala sampai sekarang. Kegiatan ini khususnya bagi pemuka adat masyarakat Tolaki yang menguasai dan membahas pekuku tula-tula;

4. Pekuku mbinekuku, artinya silsilah Tolaki yang sudah ditelusuri atau dicari-cari dari kalangan keluarga, kampung-kampung atau desa, kecamatan dan kabupaten/kota, bahkan di luar wilayah Konawe dan Mekongga, hingga dalam negeri maupun di luar negeri.

Dari keempat model kukuaha ini, pekuku mbinekuku inilah yang menjadi pokok bahasan dalam tulisan ini. Pekuku mbinekuku dianggap penting bagi masyarakat Tolaki karena pengetahuan tentang asal-usul atau garis keturunan seseorang sangat penting dalam menentukan kedudukan seseorang dalam kehidupan sosial, meskipun ada sekelompok orang Tolaki yang merasa tidak peduli lagi dengan garis keturunan asal-usul dari keturunan mana seseorang berasal. Kedudukan dan status sosial yang diperoleh dianggap sudah cukup memenuhi eksistensi mereka dalam masyarakat tanpa harus mengetahui silsilah atau asal-usul mereka.

Selanjutnya, proses pembacaan dan penelusuran silsilah oleh komunitas suku Tolaki ditentukan berdasarkan kesepakatan sistem pembacaan yang dikaitkan filosofi kalosara sebagai pedoman adat dalam tradisi suku Tolaki. Filosofi kalosara sangat berperan bagi masyarakat Tolaki dalam hubungannya dengan sistem kekerabatan dan stratifikasi sosial. Kalosara atau yang biasa juga disebut kalo adalah sebuah benda yang berbentuk lingkaran, terbuat dari tiga utas rotan yang dililitkan ke arah kiri berlawanan dengan jarum jam. Dua ujung lilitan tersebut disimpulkan atau diikat, sedangkan ujung yang satunya dibiarkan mencuat. Lilitan tiga utas rotan tersebut memiliki makna terdiri atas satu kesatuan dalam stratifikasi sosial masyarakat Tolaki. ${ }^{1}$

\section{a. Mekuku dalam Bentuk Pertanyaan}

Dalam mekuku ada ujaran, pertanyaan, dan sapaan yang khas yang telah ditentukan urutan-urutannya berdasarkan aturan yang telah disepakati secara adat. Pertanyaan-pertanyaan tersebut bertujuan untuk memeroleh persamaan status, hubungan kekerabatan, hubungan darah dalam silsilah keluarga. Tiga pertanyaan pokok yang ada dalam pertanyaan tersebut:

1. Mbe a'amu?

Darimana asalmu?

2. Inae ana motu'amu?

'Siapa orang tuamu?'

3. Mbe pepeue' amu?

'Siapa dan darimana asal nenek moyangmu?"

Pertanyaan-pertanyaan ini merupakan dasar untuk memeroleh jawaban berupa uraian dan penyampaian silsilah dalam bentuk narasi yang isinya berupa sejarah wilayah yang dikaitkan dengan asal-usul penguasa di wilayah tertentu. Bagi masyarakat Tolaki, identitas seseorang dapat ditentukan melalui penelusuran silsilah asal daerah. Oleh karena itu, daerah atau wilayah tertentu yang menjadi daerah asal seseorang akan berpengaruh dalam menentukan status seseorang.

\section{b. Mekuku dalam Bentuk Prosa}

Berikut ini teks kukuaha yang berkaitan dengan asal mula terbentuknya wilayah atau daerah yang dianggap memiliki latar belakang atau silsilah sejarah yang penting. Teks ini berbentuk prosa (cerita legenda). Kukuaha seperti ini biasanya berisi asal mula kedatangan Keluarga Raja dari wilayah tertentu yang selanjutnya menentukan garis silsilah seseorang. Contoh berikut merupakan asal

\footnotetext{
${ }^{1}$ Lebih lengkap tentang konsep kalosara dapat dibaca dalam buku Hukum Adat Orang Tolaki (2011) dan Kebudayaan Tolaki (1993).
} 
mula kedatangan Raja Tooto/Mokole Toondu di Tanah Tekaleano-Waturapa.

Konon, situasi di Kerajaan Konawe luluh lantak akibat adanya wabah penyakit yang melanda Negeri Konawe. Tokoh Onggabo yang menikahi Puteri Podesuma (gelar Kambuka Sioropo, Puteri Mokole yang selamat dari bahaya), kemudian berhasil menata kembali kehidupan negeri yang telah berantakan. Situasi kerajaan semakin membaik pada era pemerintahan cucunya, Mokole Wealanda.

Diriwayatkan bahwa Weandala dan adiknya Wealanda dinikahi oleh seorang bangsawan pendatang dari Muna yang dikenal dengan nama Elu Langgai. Wealanda melahirkan seorang putera bernama Halu Oleo, adapun Weandala melahirkan empat orang putra-puteri, di antaranya bernama Melamba yang kemudian naik tahta Konawe di awal abad ke-16.

Dalam masa pemerintahan Mokole Melamba, kedaan Negeri Konawe kembali terguncang akibat pecahnya konflik antara orang Tolaki dengan orang Moronene. Pertikaian yang berlangsung cukup lama hingga akhirnya dengan bantuan Halu Oleo dapat dikendalikan (yang mengakibatkan bergesernya orang Moronene ke arah Rumbia dan Poleang). Pada masa konflik inilah Raja Tootoo dan Mokole Toondu mengukir prestasi dengan menguasai dan mengamankan wilayah Konawe Selatan.

Paruh kedua abad ke-16 hingga awal abad ke-17, Mokole Tebawo memerintah Kerajaan Konawe. Ia mewarisi keadaan negeri yang sepenuhnya belum pulih dari ancaman konflik dari berbagai penjuru dan wilayah kerajaan itu sendiri. Untuk menghindari kekosongan penduduk dan kekosongan pemerintahan lokal, maka pada masa pemerintahan Mokole Tebawo dibuatlah sistem pertahanan keamanan wilayah yang dikenal dengan sebutan sistem siwole mbatohu. Sistem pemerintahan ini membentuk dua dewan yang berpusat di kerajaan dan satu dewan di pemerintahan lokal/daerah. Dua dewan yang berpusat di kerajaan disebut dewan kerajaan dan dewan kabinet. Dewan kerajaan diisi oleh enam jabatan pusat, yaitu mokole, sulemandara, kotu bitara, purutobu tuoi, tutuwi motaha, dan inea sinomu atau raja muda. Selanjutnya, dewan kabinet diisi oleh tujuh jabatan birokrasi yang disebut pitu dula batuno Konawe.

Dewan yang dibentuk pada pemerintahan lokal/daerah meliputi para pejabat puutobu yang dibantu oleh para toono motuo di bawah pimpinan pejabat sulemandara yang sekaligus berfungsi dan bertindak sebagai majelis besar adat Konawe. (Toondu, 2011: 3)

Selain tuturan yang bertujuan untuk mengetahui asal-usul wilayah atau daerah, kukuaha juga dituturkan untuk mengetahui silsilah raja-raja untuk mengetahui garis keturunan/darah seseorang yang dapat menentukan status tertentu. Kukuaha seperti ini biasanya dilakukan dalam beberapa versi penceritaan bergantung penuturnya. Berikut ini dua versi penceritaan kukuaha tentang raja-raja Tolaki untuk mengetahui silsilah atau garis kebangsawanan seseorang.

\section{1) Versi pertama}

Dikisahkan bahwa pada zaman pemerintahan Sangia Inato, ipar Sangia Inato bernama Buburanda menjelajahi daerah pantai selatan daerah Sulawesi Tenggara bersama istrinya yang bernama Weleka (adik Sangia Inanto) yang kemudian bermukim di Lapulu. Di daerah inilah Mbatono dilahirkan. Buburanda adalah putra dari Silondae I, yaitu salah satu cucu keturunan Onggabo, Mbatono dewasa dengan perangai yang sangat berani. Dengan didampingi oleh Tokase sebagai Tamalaki Owose memerangi suku Moronene yang bermukim di wilayah Motaha, Benua, Tinanggea, Palangga, Laeya. Kondisi ini menyebabkan orang Moronene terdesak dan mencari pemukiman baru ke wilayah Poleang, Rumbia dan menyebar hingga ke Pulau Kabaena. 
Setelah keberhasilannya melakukan ekspansi ke wilayah Moronene, Mbatono kembali ke Konawe dan melaporkan keberhasilannya pada Sangia Inanto. Dengan keberhasilannya itu, melalui seorang Lasaima $^{2}$, Mbatono dilantik menjadi Mokole Andolo atau Raja Tolaki yang memegang kekuasaan di wilayah Andoolo (Silondae, 2010: 24).

\section{2) Versi Kedua}

Kukuaha yang menceritakan silsilah raja-raja Tolaki dan turunannya versi kedua $^{3}$ dapat dilihat seperti berikut ini:

Dikisahkan bahwa Buburanda yang telah berkuasa di Wowalatoma memiliki anak yang bernama Mbatono dan Wungabae dari hasil perkawinannya dengan Weleka, adik kandung Raja Maago (Sangia Mbinauti). Setelah dewasa, Mbatono yang saat itu kira-kira berusia 20 tahun meminta/menuntut pembagian kekuasaan. Adapun adiknya Wungabae menikah dengan Teporambe (pewaris gelar raja Mekongga yang dijuluki Sangia Nilulo.

Ayah mereka, Buburanda pun menunjuk suatu tempat/wilayah di sebelah selatan Kerajaan Konawe, yang bukan menjadi wilayah kekuasaan Kerajaan Konawe (saat itu masuk dalam kekuasaan Moronene. Buburanda memberi syarat pada Mbatono, jika berhasil menguasai atau menaklukkan wilayah tersebut secara paksa atau melalui peperangan, maka Mbatono boleh menguasai wilayah tersebut dan menjadi raja di sana.

Setelah diberi ketentuan seperti itu, maka di bawah pimpinannya, Mbatono berangkat bersama rombongannya dari Latoma dan Konawe menuju daerah

2 Pejabat pemegang arsip Kerajaan Konawe yang mempunyai tugas dan wewenang untuk melantik raja-raja Tolaki di wilayah-wilayah yang tersebar di Kerajaan Konawe.

3 Kukuaha versi kedua ini diceritakan oleh Budu S, mantan Kepala Desa Andowia yang menjabat selama 20 tahun, kukuaha ini dituturkan pada tahun 2004 .
Moronene tersebut. Pada saat itu, rombongan Mbatono terdiri atas Patombolu Lausa (40 rumah tangga yang masing-masing terdiri atas suami istri dan anak), dan Patambolu Tamalaki (40 orang bala tentara beserta keluarga mereka) yang dipimpin oleh Tokase sebagai Tamalaki Owose, sehingga jumlah rombongan besar yang dibawa oleh Mbatono lebih dari 100 orang. Perjalanan mereka ditempuh dengan menggunakan alat angkut sederhana berupa rakit melalui Sungai Konawe'eha.

Persinggahan mereka yang pertama di daerah yang disebut Sabilakoa yang berarti 'saksi perjalanan' kemudian dilanjutkan dengan berjalan kaki selama beberapa hari hingga sampai di daerah hutan yang sama sekali tidak berpenghuni. Rombongan Mbatono pun sepakat untuk memberi nama daerah tersebut dengan Andoolo yang berarti 'hutan rimba'.

Selanjutnya rombongan Mbatono inilah yang pertama kali membuka wilayah hutan tersebut menjadi daerah pemukiman hingga menjadi perkampungan ramai. Daerah yang tadinya berupa hutan belantara selanjutnya menjadi kebun/ladang penanaman padi dan jagung, serta sejumlah rumah-rumah penduduk yang mulai dibangun.

Seiring waktu, wilayah ini menjadi ramai yang dikunjungi banyak pendatang, termasuk suku Maronene yang hidup berkelompok-kelompok di wilayah yang sama. Sejak saat itu, mulailah timbul berbagai perselisihan antarsuku yang menyebabkan suku Moronene meninggalkan tempat tersebut mulai dari daerah Motaha, Benua, Andoolo, Kiaeya, Palangga, Laeya, Kolono, hingga pesisir pantai Torobulu, Lakara, dan Tinaggea.

Saat terjadi penyerangan besarbesaran di daerah Tinanggea, banyak pasukan Mbatono dan Tokase yang tewas, baik karena peperangan maupun karena wabah penyakit. Mbatono pun meminta pada Tokase untuk kembali ke Konawe untuk meminta bala bantuan Tamalaki sebanyak 40 orang. Sangia Inanto 
mengirimkan bantuan dan langsung melakukan penyerangan lagi pada suku Moronene yang masih bertahan di daerah itu. Hingga suku Morenene mundur ke daerah Lanowulu. Setelah perang usai, Mbatono pun menguasai wilayah seluruh Moronene termasuk daerah pesisir. Daerah kekuasaan Mbatono ini pun dianggap sangat strategis, selain karena adanya perkampungan yang sudah terbentuk, terdapat pula pelabuhan di daerah peisisirnya yang kemudian dikenal dengan nama ngapaaha yang artinya 'pelabuhan/dermaga'.

Selanjutnya, Mbatono memindahkan perkampungan Ando'olo di Ngapaaha dan memproklamirkan berdirinya Kerajaan Ando'olo pada tahun 1640 (Silondae, 2010: 27).

Materi mekuku berupa pertanyaan dan bentuk prosa akan dibahas pada subbab berikut.

\section{Mekuku sebagai Media Identifikasi Kelompok}

Mekuku dimaknai sebagai tradisi berkomunikasi dengan menggunakan komunikasi lisan berupa ujaran, pertanyaan-pertanyaan, atau sapaan yang khas dan telah ditentukan urutanurutannya. Sebagai salah satu bentuk komunikasi tradisional, masyarakat Tolaki dapat mengidentifikasi dan membedakan status sosial anggota dalam satu kelompok. Dengan kata lain, mekuku juga dianggap sebagai wahana penuturan sejarah atau riwayat dan peristiwa klasik orang-orang Tolaki masa lalu.

Dalam perkembangannya, mekuku menjadi tradisi berkomunikasi antara masyarakat penghasil tradisi (penutur) dengan masyarakat luar (pendatang). Ada penonjolan identitas etnik melalui berbagai pertanyaan-pertanyaan, simbol-simbol, simbol yang berkenaan dengan kata-kata, dengan tujuan adanya pemisahan atau penggolongan etnik tertentu dari golongan lain. Pada konteks ini, mekuku menjadi wahana identifikasi sosial yang bertujuan untuk mencari titik persamaan antara penutur dengan pendatang. Dalam dinamika interaksi sosial warga Tolaki mekuku merupakan sebuah tradisi klasik pada sebuah kegiatan atau acara tertentu, ketika seseorang bertemu dengan seseorang lainnya untuk pertama kali (biasanya yang lebih tua).

Pertanyaan-pertanyaan yang bersifat umum itulah menjadi awal bagi status seseorang dalam lingkungan masyarakat. Isi mekuku yang mencakup uraian, atau penyampaian silsilah dalam bentuk narasi tersebut menjadi tolok ukur ditemukannya identias seseorang. Dengan ragam tuturan itu, masyarakat Tolaki berusaha mengenali status sosial dan identitas kelompok mereka dengan yang bukan. Dengan kata lain tujuan akhir dari tradisi ini adalah mencari titik persamaan dan perbedaan antaranggota, dan antara penutur asli dengan pendatang.

\section{a. Identifikasi Berdasarkan Pertanyaan Mekuku}

Dalam Taridala (2005) diuraikan bahwa mekuku merupakan cara identifikasi dalam lingkup yang lebih luas. Cara ini ditandai dengan kalimat-kalimat interogatif dengan memberikan pertanyaanpertanyaan tertentu untuk mengetahui asalusul atau garis keturunan seseorang. Seperti yang telah disebutkan sebelumnya, ada tiga pertanyaan umum yang sering diajukan dan menjadi sapaan khas dalam mekuku yaitu 1) mbe 'ariamu? 'darimana asalmu?'; 2) inae anamotu'omu? 'siapa orang tuamu?'; 3) mbe popue 'amu? ' siapa dan darimana asal nenek moyangmu?'.

Jawaban dari pertanyaan mbe ari'amu atau 'darimana asalmu' ini dimaksudkan untuk mengetahui daerah asal seseorang. Kesatuan wilayah asal seseorang sangat menentukan status keturunan karena dikaitkan dengan sejarah atau peritiwa masa lalu. Seseorang yang ditanya tentang asal daerahnya cenderung akan menjawab dengan menyebut kesatuan wilayah adatnya, bukan secara spesifik menyebutkan nama desa asalnya. Misalnya, seseorang yang berasal dari 
salah satu dari desa di Abuki (seperti Sambeani, Punggaluku, Asolu, Lasada), ketika ditanya tentu akan menjawab dengan menyebut asal daerah Abuki, karena Abuki dikenal sebagai kesatuan wilayah adat klasik yang memiliki gelar Inea Sinomu, yang pada masa lalu merupakan tempat kedudukan tiga penguasa adat pemerintahan Kerajaan Konawe atau yang dkenal dengan sebutan O Tolu Benggi Pono.

Pada umumnya, nama daerah atau wilayah yang lebih luas cenderung digunakan atau disebutkan sebagai tempat seseorang berasal. Bagi masyarakat Tolaki penyebutan nama wilayah tertentu yang memiliki keterkaitan sejarah dari sisi geopolitik dengan wilayah kerajaan-kerajaan masa lalu sangat penting dalam proses interaksi, khususnya dalam menaikkan nilai atau derajat seseorang.

Pertanyaan yang kedua yaitu inae anamotu'omu atau 'siapa orang tuamu' dimaksudkan untuk mengetahui silsilah garis keturunan dan latar kekerabatan seseorang. Jawaban dari pertanyaan ini akan berkaitan erat dengan penilaian secara subjektif terhadap status sosial pada masa sekarang. Ketika seseorang ditanya dengan pertanyaan tersebut, biasanya dijawab dengan menyebutkan satu nama yang menunjukkan gelar khusus dari rumpun keluarga tertentu. Orang yang menjawab pertanyaan tersebut, yang menyebutkan bahwa dirinya memiliki hubungan atau menyandang gelar dengan status sosial tinggi, biasanya mengharapkan penilaian lebih tentang diri dan perilaku dari orang yang mengajukan pertanyaan. Kesan ini tentu akan memberikan pengaruh secara psikologis dalam melakukan perannya, khususnya dalam lingkungan budaya yang sama.

$$
\text { Adapun pertanyaan mbe }
$$

рорие'ати atau 'siapa dan darimana nenek moyangmu' dimaksudkan untuk mengetahui tingkat kebangsawanan seseorang dari garis keturunan satu nenek moyang yang sama atau tidak, memiliki garis kebangsawanan Anakia atau sebaliknya dari golongan kelas menengah, atau masyarakat biasa. Jawaban dari pertanyaan tersebut juga berkaitan dengan sikap subjektivitas seseorang saat menyebut daerah asal seseorang. Penyebutan nama dan asal kakek atau nenek moyang biasanya akan memengaruhi sikap diri orang tersebut sebagai pribadi yang mewakili rumpun keluarga tertentu. Ada anggapan bahwa orang yang mengajukan pertanyaan mbe рорие'ати akan memiliki sikap dan pandangan yang berbeda jika telah mengetahui asal-usul orang yang diajak bicara tersebut.

Hubungan antara penutur sebagai satu bentuk sistem komunikasi, dalam hal ini antara penutur dengan yang mendengarkan atau menerima tuturan sebagaimana jika diterapkan dalam sistem mekuku, sama seperti teori tentang hubungan kekuasaan atau solidaritas yang dikemukakan oleh Brown dan Oilman (dalam Hoed, 2008: 189-191). Inti dari teori tersebut adalah hubungan antara pembicara dan yang diajak bicara dapat bertumpu pada poros 'kekuasaan' yaitu bahwa derajat mereka tidak sama tinggi, atau pada poros 'solidaritas' bahwa hubungan antara pembicara dengan yang diajak bicara berada dalam tingkatan yang sama. Dalam poros 'solidaritas dibedakan lagi dalam hubungan 'akrab' dan 'tidak akrab'. Poros-poros itu berkaitan dengan penggunaan pronomina orang kedua tunggal. Pada tulisan Browman dan Oilman (dalam Hoed, 2008) tersebut dikemukakan bahwa perbedaan itu mengakibatkan penggunaan pronomina orang kedua tertentu. Jika dilihat dari poros tinggi-rendah, maka pasangan pronomina yang dipilih adalah $\mathrm{T}$ (tinggi) $\mathrm{V}$ (rendah). Jika dilihat dari poros akrabtidak akrab, maka yang dipilih adalah salah satu dari dua pronomina yang ada ( $\mathrm{T}$ atau V).

Simbol tidak hanya berkenaan dengan kata-kata. Namun dalam tradisi mekuku masyarakat Tolaki simbol berupa kata-kata sangat dipentingkan, khususnya 
dalam mengidentifikasi seseorang, apakah berasal dari budaya yang sama ataupun dari budaya yang berbeda. Tanda dalam hal ini adalah bahasa atau kata-kata yang berupa pertanyaan-pertanyaan, sedangkan penandanya atau makna adalah makna dari pertanyaan-pertanyaan itu. Mekuku dengan cara ini merupakan proses komunikasi yang terjadi dengan penonjolan identitas etnik melalui berbagai pertanyaanpertanyaan yang terdiri atas kata-kata, simbol-simbol, simbol yang berkenaan dengan kata-kata, dengan tujuan adanya pemisahan atau penggolongan etnik tertentu dari golongan lain. Dengan ragam pertanyaan itu masyarakat Tolaki berusaha mengenali identitas kelompok mereka dengan yang bukan.

Seperti yang telah diuraikan sebelumnya bahwa ada dua pendekatan yang dapat dilakukan terhadap identitas etnik, pendekatan objektif (struktural) dan pendekatan subjektif (fenomenologis). Dengan demikian, jika kita menggunakan prespektif objektif maka kita akan melihat sebuah kelompok etnik berdasarkan ciri budayanya, seperti bahasa, agama, dan asal-usul. Gagasan identitas etnik melalui pertanyaan-pertanyaan pada tradisi mekuku dapat menghubungkan konsep identitas etnik dengan konsep identitas diri. Istilah identitas diri (self-identity) adalah inti diri (the core self), yaitu posisi umum seseorang dalam masyarakat (Kuhn dalam Mulyana dan Rachmat, 1998: 152).

Proses identitas etnik dalam tradisi mekuku pada prespektif objektif ini hanya ada dalam tahapan pertama, yaitu tahap pengenalan. Ketika X (orang yang ditanya) dikenal atau diketahui mempunyai identitas yang sama, maka selanjutnya ia akan melanjut pada tahap kedua, yaitu tahap mengenai penjelasan asal-usul sejauhmana keterikatan si $\mathrm{X}$ dengan kelompok etnis itu. Dalam hal ini, komunikasi yang diciptakan dalam tradisi mekuku adalah komunikasi dalam hubungan poros 'kekuasaan'. Dalam hal ini kita menganggap bahwa pada tahap pertama, penutur menempatkan dirinya lebih tinggi dari orang yang ditanya. Dalam tahap kedua atau tahap selanjutnya, penutur akan menempatkan dirinya sejajar atau 'hubungan akrab' dengan orang yang ditanya apabila berasal dari etnik yang sama.

Kelompok masyarakat Tolaki atau yang dikenal dengan sebutan LAT, sebagai salah satu lembaga atau kelompok etnik yang besar dapat mewakili identitas etnik masyarakat Tolaki. Ketika Y diketahui bukan dari kelompok yang sama, maka si Y tidak akan mendapat pertanyaan pada tahap kedua atau tahap selanjutnya, maka $\mathrm{Y}$ adalah stranger atau orang asing di luar kelompok etnik mereka.

\section{b. Identifikasi Melalui Prosa (Cerita Rakyat)}

Cara identifikasi kelompok yang kedua dalam mekuku adalah melalui prosa (Syawal, 2011). Prosa merupakan jenis karya sastra. Ketika membahas tentang kukuaha berbentuk prosa ini tentu tidak bisa dilepaskan dari struktur yang membentuknya, seperti cerita, alur, tokoh, penokohan yang wajib dimiliki sebuah karya sastra. Menurut Ratna (2011: 154) karya sastra pada umumnya mengutamakan penyajian adalah segalagalanya. Bahwa karya sastra adalah penyajian suatu peristiwa yang sangat terikat dengan bahasa sebagai medium yang digunakan. Bentuk komunikasi kukuaha dengan cara prosa ini biasanya dilakukan secara tertulis dan lisan. Bentuk tertulis disajikan dalam bentuk teks historiografi. Adapun secara lisan dibacakan atau dituturkan sesuai dengan teks yang ada.

Historiografi kukuaha terdiri atas beberapa bab, yang diawali dengan bab pertama berupa latar belakang yang menguraikan sejarah terbentuknya rumpun keluarga tertentu, terbentuknya wilayah, dan silsilah keluarga secara turun-temurun. Bab kedua berisi asal mula kedatangan sebuah rumpun keluarga, serta hubungannya dengan raja-raja dan pusat pemerintahan pada masa lalu; bab ketiga berupa uraian tentang silsilah rumpun 
keluarga yang memiliki eksistensi dalam kepemimpinan kultural; bab keempat berupa penyajian fakta-fakta berupa dokumen sejarah dan hubungan kekerabatan secara turun-temurun; serta keberadaan sebuah rumpun keluarga sebagai sebuah komunitas etnis yang diakui.

Uraian tentang silsilah dan asalusul seseorang dalam kelompok masyarakat Tolaki dapat diketahui melalui cerita berbentuk legenda. Secara struktural gaya bertutur mekuku melalui cerita seperti pada umumnya struktur umum sebuah prosa. Cara mekuku dengan prosa biasanya memiliki tema yang sama, yaitu cerita tentang tokoh raja dan pemimpin atau penguasa wilayah adat. Fokus penceritaannya ditekankan pada nama tokoh dan latar tempat. Kedua unsur ini pada dasarnya masih berkaitan erat nama dengan pertanyaan mekuku seperti yang telai diuraikan sebelumnya. Dalam proses penuturannya, mekuku dengan cara prosa berbeda dengan mekuku berupa pertanyaan-pertanyaan, mekuku dengan cara prosa ini isinya sangat mementingkan tema, alur, dan waktu.

Mekuku dengan cara prosa ini biasanya juga dilakukan dalam proses penyelesaian sengketa terhadap penguasaan tanah wilayah. Dengan kata lain bahwa kukuaha (silsilah) dalam perkembangannya memiliki peran penting dalam bidang hukum. Pada deskripsi kukuaha yang telah diuraikan sebelumnya, merupakan salah satu contoh bentuk historigrafi silsilah keluarga yang dapat digunakan untuk penyelesaian kasus sengketa atas hak kuasa tanah tertentu. Dalam hal ini, kukuaha telah menjadi satu tradisi komunikasi yang diakui secara hukum meskipun dituturkan secara adat. Penonjolan peran dan tokoh legendaries dalam deskripsi kukuaha dijadikan sebagai fakta sejarah tentang sebuah hubungan masa lalu dan masa sekarang dalam upaya menegakkan hak-hak sebuah rumpun keluarga. Penonjolan identitas etnis yang dalam deskripsi kukuaha tampak dalam tokoh (bergelar raja atau bangsawan), karakter tokoh (pemberani, pejuang), dan motif (yang menunjukkan kemampuan menguasai wilayah tertentu). Ketiga unsur ini dapat dianggap sebagai upaya penonjolan identitas etnis atas konsep diri, sikap dan perilaku, dan kepercayaan atas diri seseorang.

Pada proses identifikasinya, salah satu ciri yang dapat dikenali dari mekuku melalui prosa yang biasa digunakan sebagai media dalam menyelesaikan sebuah proses hukum atas sengketa tanah atau wilayah tertentu adalah adanya penggunaan kalimat-kalimat performatif dalam situasi resmi. Gaya mekuku dapat dikenali dari ucapan salam pembuka, misalnya kalimat "inggomiu mberi'ou" yang artinya "yang terhormat bapak/ibu", kalimat "Saudara-saudaraku rumpun keluarga toondu mokole...(menyebutkan nama gelar kebangsawanan), atau dengan kalimat "Yang mulia majelis hakim dan wakil syara adat dari keturunan Mokole...(menyebut nama raja Konawe atau Mekongga). Mekuku dengan cara prosa ini biasa digunakan dalam sebuah penyelesaian hukum keluarga, misalnya dalam upaya menegakkan hak-hak rumpun atas sebuah warisan keluarga.

Penggunaan bahasa performatif dalam setelah tuturan kukuaha tersebut lazim digunakan dan umumnya hanya digunakan oleh pemuka adat atau orangorang yang telah ditunjuk dan memiliki kedudukan sosial tertentu. Dengan kata lain penggunaan bahasa performatif dalam kukuaha dengan cara prosa ini digunakan dalam situasi resmi. Dalam konteks komunikasi budaya, bahasa performatif dalam kukuaha dengan cara prosa hanya dilakukan dalam lingkungan komunitas yang sama, penutur yang sama, dan bukan terjadi dalam hubungan komunikasi budaya yang berbeda.

Upaya penunjukkan identitas diri secara etnis dapat diterima dalam komunitas yang sama hanya untuk menunjukkan status sosial seseorang. Berbeda halnya jika penonjolan identitas 
etnis tersebut dilakukan dalam konteks budaya yang berbeda, dengan kata lain proses ini hanya merupakan upaya untuk menonjolkan ciri komunitas secara universal, bukan ciri diri. Artinya, penggunaan bahasa kukuaha dilakukan untuk menunjukkan dua fungsi, yaitu fungsi menonjolkan identitas diri dan fungsi menonjolkan ciri komunitas.

Secara fenomenologis, proses komunikasi kukuaha ini telah menjadi kekuatan sosial bagi masyarakat Tolaki untuk menunjukkan konsep diri mereka sebagai kelompok sosial yang berbeda dalam sebuah wilayah kultural yang homogen. Sikap antroposentrisme dalam tradisi mekuku dalam proses menuturkan perjalanan seseorang dalam bentuk cerita panjang (prosa) yang dikaitkan dengan legenda tertentu, menjadi ciri komunikasi kultural yang hingga saat ini masih dianggap sesuai dalam dunia komunikasi yang telah mencapai era teknologi modern.

Selanjutnya, mekuku biasa juga digunakan dalam proses hukum adat, seperti penyelesaian tanah sengketa yang biasanya dapat diketahui silsilah kepemilikannya melalui mekuku. Tentang identifikasi kelompok melalui mekuku dan penerapan mekuku dalam proses hukum adat dapat dilihat dalam uraian berikut.

\section{b) Penerapan Mekuku dalam Hukum Adat}

Mekuku yang dijadikan tradisi sebagai cara bertutur silsilah (kukuaha) memiliki fungsi sosial sebagai sebuah proses komunikasi dalam satu komunitas budaya yang sama. Selain berfungsi sebagaimana yang telah diuraikan sebelumnya, secara adat, masyarakat Tolaki mengenal pembagian penguasaan wilayah secara adat sebagai bagian dari silsilah rumpun keluarga pada masa lalu. Dalam kaitannya dengan penguasaan tanah secara adat, kukuaha menjadi salah satu media komunikasi yang dapat digunakan untuk menerapkan hak seseorang atau rumpun keluarga tertentu dalam penguasaan tanah tertentu.
Prinsip-prinsip dasar yang ada pada hukum adat tolaki, salah satu di antaranya adalah penguasaan dan pemilikan tanah. Penguasaan tanah adat yang didasarkan pada silsilah dan tempat kediaman leluhur berkembang secara terus menerus hingga kini tetap ada dan diakui oleh masyarakat adat tolaki. Di atas tanahtanah adat biasanya terdapat kuburan leluhur yang sudah berabad-abad lamanya bahkan ada sebagian masyarakat dari generasi keturunan mereka yang meninggal tetap memilih tempat penguburannya di sekitar kediaman tanah leluhur mereka.

Suku Tolaki mengenal pembagian hak atas tanah adat yang dapat dimiliki secara pribadi (hanu dowo) dan hak dapat dimiliki secara pribadi hukum (hanuno toono dadio atau hanuno o'kambo) yang disebut hak ulayat atau common property.

Hak-hak atas tanah adat tersebut dapat dibagi atas dua jenis, yaitu

1. Hanuno o'kambo atau hanuno toono dadio, yaitu hak persekutuan hukum atas tanah sebagai milik kampung atau milik orang banyak.

2. Mbumbu kambo atau mbumbu poiaha, yaitu hak perorangan atas tanah menurut adat Tolaki adalah suatu hak yang pada asasnya hanya diberikan kepada warga persekutuan hukum secara perorangan atas sebidang tanah dalam lingkungan persekutuan hukum yang bersangkutan.

Adapun hak-hak atas tanah yang dianggap milik adat Tolaki harus memenuhi ketentuan dan syarat, yaitu

1) Ombuno atau mbumbu hapo-hapo atau mbumbu wuta, yakni kebebasan mempergunakan dan menikmati dalam batas-batas yang ditentukan oleh hukum adat (sarano wonua). Hak milik atau hanu dowo yang memberikan kepada pendukung haknya (pemiliknya). Artinya dengan hak itu dapat dilakukan segala macam transaksi 
atau perbuatan hukum atas tanah tersebut, misalnya untuk meminjamkannya kepada orang lain (mesarungge), menjual lepas (meolike), dan sebagainya.

2) Hak menikmati, yaitu hak satu-satunya yang dipunyai oleh seseorang yang bukan warga persekutuan hukum di mana tanah bersangkutan berlokasi, artinya bagi orang yang bukan penduduk setempat atau bukan keturunan dari kampung itu (toono suere) boleh saja menguasai dengan catatan harus ada izin dari persekutuan hukum (toono motuoono o'kambo) untuk membuka atau mengolah dan mengambil atau menikmati hasilhasilnya selama setahun atau lebih.

3) Hak wenang pilih atau hak mendahului (tetembele'esu), yaitu pemberian kewenangan pendudukan hak untuk memilih lebih dahulu sesuatu dan memberikan keutamaan baginya dibandingkan dengan pihak-pihak lainya.

4) Hak pungut hasil karena jabatan, yaitu suatu hak atas tanah yang dipunyai oleh kepala persekutuan (puutobu, tono motuo, anakia). Menurut prinsip hukum adat Tolaki, hak ini bersifat terbatas karena hanya dimiliki oleh kepala persekutuan hukum tingkat pusat atau kerajaan dan tingkat gabungan dari beberapa sub persekutuan hukum (otobu) yang disebut puutobu.

5) Hak pakai (mombake atau mosaru), hak ini adalah hak atas tanah yang diberikan kepada seseorang untuk digunakan dalam suatu golongan (wutano suere ndono), misalnya tanah pusaka (wuta inembue) yang penerimaannya adalah salah seorang anggota golongan itu. Hak ini disebut wuta pinesarungako yang dapat dipakai oleh yang diberi sampai yang memberi belum membutuhkannya.

6) Hak gadai (pinepoindi ngako) adalah hak seseorang atas tanah orang lain selama tanah itu belum ditebus kembali.
7) Tanah wakaf (wuta pombowehino toono) adalah tanah yang diserahkan untuk kepentingan suatu badan keagamaan atau badan sosial.

Dengan adanya ketentuan-ketentuan atas hak penguasaan tanah, mekuku dengan cara prosa dilakukan untuk menyelesaikan sengketa yang terjadi. Biasanya, berdasarkan urutan cerita, silsilah yang terkandung dalam cerita atau kukuaha, bisa ditelusuri status kekerabatan seseorang sehingga selanjutnya dapat ditentukan siapa saja yang berhak atas penggunaan dan pemilikan tanah adat.

\section{PENUTUP}

Mekuku merupakan sebuah sistem dalam bersikap (self eksistence), berkomunikasi dan berinteraksi (social communication and interaction), sebagai sebuah penanda etnis dalam lingkungan budaya yang berbeda (self-culture eksistence).

Masyarakat Tolaki menyadari pentingnya keberadaan tradisi mekuku di zaman ini mengingat sebagian anak-anak dan remaja sebagai generasi penerus adat Tolaki mulai menganggap mekuku sebagai sebuah tradisi yang tidak lagi sesuai dengan perkembangan zaman. Padahal, mekuku justru merupakan satu bentuk bertutur tradisional yang tetap dapat diterapkan di masa kini dan masa mendatang. Membaca silsilah untuk mengetahui asal usul atau garis keturunan seseorang untuk mengetahui riiwayat kebangsawanan seseorang, bukan hal yang baru dalam kehidupan sosial budaya masyarakat pada umumnya. Tetapi bagi masyarakat Tolaki, kegiatan seperti mekuku sangat penting dan harus terus dilakukan hingga di masa mendatang. Dalam masyarakat yang heterogen, bagi masyarakat Tolaki, silsilah seseorang menjadi penting untuk diketahui agar dapat eksis di setiap tingkatan hubungan sosial, mulai dari lingkup keluarga hingga ke hubungan antarbudaya.

Bentuk komunikasi mekuku yang menggunakan kalimat interogatif dan 
bentuk prosa, bukan hanya sekadar ujaran atau cerita yang dibacakan. Kedua bentuk pengungkapan ini mengandung makna tentang hubungan antara satu sama lain, baik itu dalam komunitas budaya yang sama, maupun budaya yang berbeda.

Terakhir, saran yang dapat disampaikan terkait dengan persoalan tradisi bertutur ini adalah perlunya pemeliharaan dan pelestarian dalam tradisi ini. Melalui tulisan ini diharapkan para generasi muda Tolaki dapat menyadari pentingnya tradisi bertutur ini bagi mereka sebagai suku Tolaki dan bagi orang lain sebagai satu bentuk pemeliharaan dan pelestarian tradisi. Bukan hanya asal-usul seseorang yang dapat ditelusuri dan diketahui melalui tradisi ini, lebih dari itu, pengetahuan tentang sejarah dan asal-usul wilayah dan raja-raja di masa lalu dapat diketahui oleh generasi muda melalui teks $m e k u k u$, berupa cerita sejarah, legenda, dongeng, mite yang pada dasarnya merupakan bagian dari pengetahuan tentang sastra baik lisan maupun tulisan.

Keunikan sebuah tradisi dalam suatu kelompok masyarakat tidak sekadar hanya menjadi ciri khas dalam kelompok tersebut. Tetapi menjadi penanda bahwa masyarakatnya memiliki tradisi yang dikenal oleh masyarakat di luar komunitas penutur tradisi tersebut. Mengingat arah pengembangan bahasa, sastra, dan tradisi lokal difokuskan pada menjadikannya sebagai bagian dalam khazanah kekayaan budaya nasional. Pemahaman tentang sebuah bentuk atau sistem pengungkapan budaya terhadap identitas pada satu kelompok masyarakat agar terlaksana secara utuh, tidak saja oleh penuturnya, tetapi juga oleh indvidu luar kelompok penutur. Ini akan memberikan satu peluang bagi pemberdayaan potensi bahasa, sastra, dan budaya daerah.

\section{DAFTAR SUMBER}

Abdullah, Nurdin. 2009
Silsilah Tolaki “Kukuaha”. Malang: Universitas Malang Press.

Chaer, Abdul dan Leonie Agustina. 2004. Sosiolinguistik Perkenalan Awal. Jakarta: Rineka Cipta.

Eilers, Josepf- Franz. 1995. Communicating Between Cultures: An Introduction to Intercultural Communication, Berkomunikasi Antara Budaya. Terj. John Tondowidjodjo. Ende: Nusa Indah.

Hoed, B.H. 2008

"Komunikasi Lisan sebagai Dasar Tradisi Lisan" dalam Juentia (ed.) Metodologi Kajian Tradisi Lisan. Jakarta: ATL, hlm. 184-194.

Koodoh, Erens E.,dkk. 2011.

Hukum Adat Orang Tolaki. Yogyakarta: TERAS.

L. Tubbs, Stewart and Sylvia Moss. 2000. Human Communication, KonteksKonteks Komunikasi. Terj. Mulyana Deddy dan Gembirasari. Bandung: Remaja Rosdakarya.

Mulyana, Deddy dan Jalaluddin Rakhmat. 1998 (Ed.).

Komunikasi Antarbudaya. Bandung: Remaja Rosdakarya.

Ratna, Nyoman Kutha. 2011.

Antropologi Sastra Peranan Unsurunsur Kebudayaan dalam Proses Kreatif. Yogyakarta: Pustaka Pelajar.

Ratna, Nyoman Kutha. 2007.

Sastra dan Cultural Studies. Yogyakarta: Pustaka Pelajar.

Sedyawati, Edi. 1996.

"Kedudukan Tradisi Lisan dalam Ilmu-Ilmu Sosial dan Ilmu Budaya", dalam Warta ATL Edisi II, Maret. Jakarta: ATL.

Silondae, Syawal. 2010

Sejarah Andoolo Konawe Selatan. Kendari, tidak diterbitkan.

Suhardi, B., dan B. Cornelius Sembiring. 2007. "Aspek Sosial Bahasa", dalam Kushartanti, dkk (Ed.), Pesona Bahasa: Langkah Awal Memahami Linguistik. hlm. 47 - 62. Jakarta: Gramedia Pustaka Utama. 
Taum, Yoseph Yapi. 2011.

Studi Sastra Lisan. Yogyakarta:

Lamalera.

Taridala, Yusran. 2005.

Perubahan Sosial pada Masyarakat

Tolaki. Kendari: Yayasan Hijau Sejahtera.

Tarimana, Abdulrauf. 1993.

Kebudayaan Tolaki. Jakarta: Balai Pustaka.

Toondu, Hasan. 2011.

"Historiografi Rumpun Keluarga Raja Tooto dan Toondu di Tanah Waturapa Konawe Selatan". Kendari, tidak diterbitkan.

Zaimar, Okke K.S. 2008.

Semiotik dan Penerapannya dalam Karya Sastra. Jakarta: Departemen Pendidikan Nasional. 